\title{
Sensitive Gas Chromatography Detection of Nanomolar Hydroxylamine in Environmental Water by Fe(III) Oxidation
}

\author{
Aiko Hikino, ${ }^{* 1}$ Shogo Sugahara, ${ }^{* 1 \dagger}$ Toshikuni Kato, ${ }^{* 2}$ Yukiko Senga, ${ }^{* 3}$ Michiko Egawa, $* 1$ \\ Ja Yeong Park, ${ }^{* 1}$ Hiroshi KamiYa, ${ }^{* 2}$ Hidekazu Tanaka, ${ }^{* 1}$ and Yasushi SeIKE ${ }^{* 4}$ \\ *1 Graduate School of Science and Engineering, Shimane University, Matsue, Shimane 690-8504, Japan \\ *2 Shimane Prefectural Institute of Public Health and Environmental Science, Matsue, Shimane 690-0122, \\ Japan \\ *3 Faculty of Science, Toho University, Funabashi, Chiba 274-8510, Japan \\ *4 Estuary Research Center, Shimane University, Matsue, Shimane 690-8504, Japan
}

\begin{abstract}
Nanomolar concentrations of $\mathrm{NH}_{2} \mathrm{OH}$ in natural water sources were determined using an $\mathrm{Fe}^{3+}$ oxidation method. A pH of $2.35-2.50$ was used, which was adjusted by adding a chloroacetate buffer. Equal amounts $(1.0 \mathrm{~mL})$ of the chloroacetate solution and ferric chloride solution were added to the water sample $(70 \mathrm{~mL})$ to oxidize $\mathrm{NH}_{2} \mathrm{OH}$ to $\mathrm{N}_{2} \mathrm{O}$. The resulting $\mathrm{N}_{2} \mathrm{O}$ in the sample water was then quantified by headspace analysis using a gas chromatograph with an electron-capture detector (ECD), where a limit of detection of $0.2 \mu \mathrm{gN} \mathrm{L}^{-1}\left(14 \mathrm{nmol} \mathrm{L}^{-1}\right)$ was achieved. This method was successfully applied to samples of freshwater, brackish water, and seawater, and despite the various salinities no interfering substances were observed. Furthermore, $\mathrm{NH}_{2} \mathrm{OH}$ was successfully detected in samples collected from the Hii River and Lakes Shinji and Nakaumi (Shimane Prefecture, Japan). In addition, the proposed method was also applicable to samples rich in organic substance derived from phytoplankton.
\end{abstract}

Keywords Brackish water, chloroacetate buffer, estuary, ferric oxidation method, gas chromatography, hydroxylamine, in situ method, nitrous oxide

(Received July 13, 2020; Accepted September 24, 2020; Advance Publication Released Online by J-STAGE October 2, 2020)

\section{Introduction}

Nitrogenous species, such as ammonia, nitrite, nitrate, hydroxylamine $\left(\mathrm{NH}_{2} \mathrm{OH}\right)$, and nitrous oxide, are recycled through microbial processes in environmental water. ${ }^{1-3} \mathrm{NH}_{2} \mathrm{OH}$ has been identified as an intermediate in nitrogen cycles, including the redox reactions between nitrite and ammonia, in aquatic and sedimentary systems. ${ }^{4,5} \mathrm{NH}_{2} \mathrm{OH}^{6,7}$ and hydrazine ${ }^{6,8}$ have attracted particular attention in recent years as an intermediate in anaerobic ammonia oxidation (Anammox). Hence, $\mathrm{NH}_{2} \mathrm{OH}$ is an important nitrogen species for understanding the nitrogen cycle.

Millimolar solutions of $\mathrm{NH}_{2} \mathrm{OH}$ are stable for several hours at $\mathrm{pH} 4.0,{ }^{9}$ but at $\mathrm{pH} 7.8$ in the presence of air, the concentration remains for only $60 \mathrm{~min} .{ }^{10}$ Thus, the direct determination of $\mathrm{NH}_{2} \mathrm{OH}$ is difficult in environmental water because of its low concentration and instability. ${ }^{11}$ However aquatic chemists and biologists are looking for very low, often nanomolar concentrations of $\mathrm{NH}_{2} \mathrm{OH}$ in natural water.

Over the last few decades, several methods for determining nanomolar concentrations of $\mathrm{NH}_{2} \mathrm{OH}$ have been developed that employ analytical techniques, such as spectrophotometry, ${ }^{12,13}$ high-performance liquid chromatography (HPLC), ${ }^{14}$ and gas

$\dagger$ To whom correspondence should be addressed. E-mail: yseike@ riko.shimane-u.ac.jp (Y. S.); suga@ riko.shimane-u. ac.jp (S. S.) chromatography (GC). ${ }^{15,16}$

Seike et al. ${ }^{15}$ have fabricated a simple method for detecting nanomolar $\mathrm{NH}_{2} \mathrm{OH}$ in freshwater samples by its oxidation to nitrous oxide $\left(\mathrm{N}_{2} \mathrm{O}\right)$ using hypochlorite as the oxidizing agent (hypochlorite method). The $\mathrm{N}_{2} \mathrm{O}$ produced in this manner was subsequently measured using a gas chromatograph with an electron-capture detector (ECD). Kato et al. ${ }^{16}$ modified this hypochlorite method, developing a quantitative method that could be applied to brackish and sea water, as well as freshwater samples. This method exhibited a limit of detection of $0.2 \mu \mathrm{gN} \mathrm{L}^{-1}\left(14 \mathrm{nmol} \mathrm{L}^{-1}\right)$ for detecting $\mathrm{NH}_{2} \mathrm{OH}$. However, we have noticed one drawback for this method, ${ }^{15,16}$ that is, in the case of samples rich in organic matter derived from phytoplankton, the amount of $\mathrm{NH}_{2} \mathrm{OH}$ detected might be underestimated.

Another method was proposed by von Breymann et al. ${ }^{17}$ that employed gas chromatography to detect $\mathrm{NH}_{2} \mathrm{OH}$ by its oxidation to $\mathrm{N}_{2} \mathrm{O}$, with $\mathrm{Fe}^{3+}$ acting as the oxidizing agent (Fe(III) method). However, only $50 \%$ conversion of $\mathrm{NH}_{2} \mathrm{OH}$ to $\mathrm{N}_{2} \mathrm{O}$ was achieved. Butler and Gordon ${ }^{18}$ modified this $\mathrm{Fe}(\mathrm{III})$ method, ${ }^{17}$ and they reported conversions of $\mathrm{NH}_{2} \mathrm{OH}$ to $\mathrm{N}_{2} \mathrm{O}$ that reached $80 \%$ $(40-83 \%)$ by adjusting the $\mathrm{pH}$ to $2.9-3.0$ using an acetate buffer. The assumed reaction for these analyses is as follows:

$$
4 \mathrm{Fe}^{3+}+2 \mathrm{NH}_{2} \mathrm{OH} \longrightarrow 4 \mathrm{Fe}^{2+}+\mathrm{N}_{2} \mathrm{O}+\mathrm{H}_{2} \mathrm{O}+4 \mathrm{H}^{+},
$$

where $\mathrm{N}_{2} \mathrm{O}$ is the sole nitrogenous end-product. In this study, we further modified the $\mathrm{Fe}(\mathrm{III})$ method $^{18}$ and attained complete 


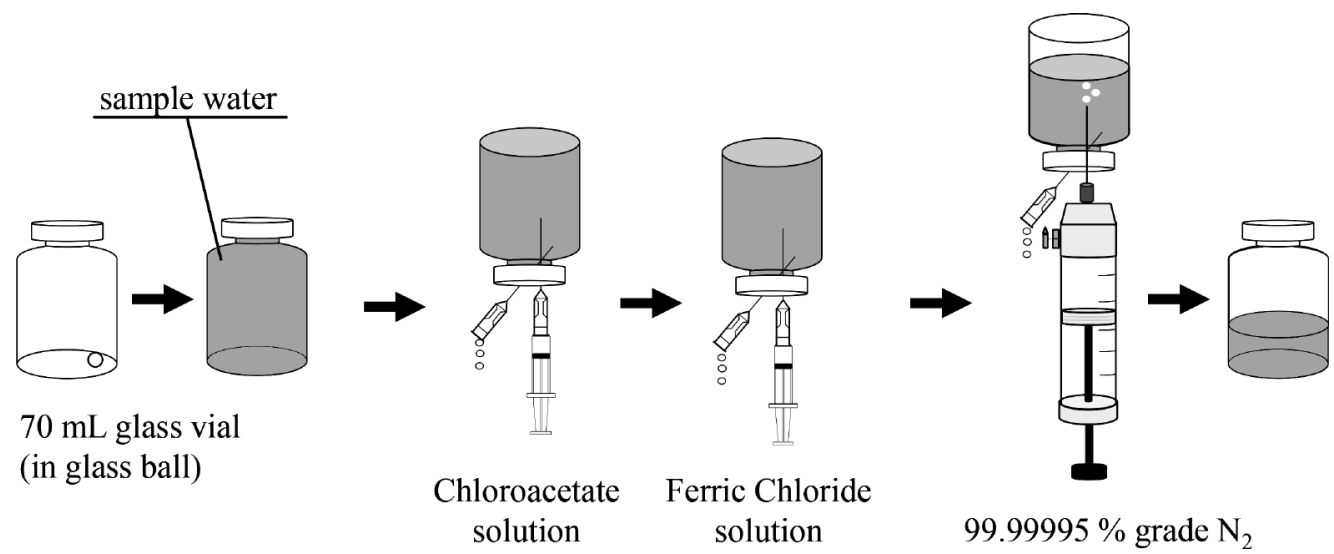

Fig. 1 Standard quantitative procedure.

conversion of $\mathrm{NH}_{2} \mathrm{OH}$ to $\mathrm{N}_{2} \mathrm{O}$. We also examined the effect of organic substances that were provided by aquatic organisms for the determination of $\mathrm{NH}_{2} \mathrm{OH}$ in natural water using our modified $\mathrm{Fe}$ (III) method.

\section{Experimental}

\section{Reagents and chemicals}

High-purity reagents (Wako, Special Class) were used in all cases. Milli-Q water (Millipore) was used for all reagent preparations.

An $\mathrm{NH}_{2} \mathrm{OH}$ standard solution ( $500 \mathrm{mgN} \mathrm{L}^{-1}$ ) was prepared by dissolving $0.2481 \mathrm{~g}$ of hydroxylamine hydrochloride in deoxygenated water and diluting it to $100 \mathrm{~mL}$. Further, suitable dilutions were made at the time of use. Fresh reagents were prepared for each experiment.

A calibration gas, $99.5 \% \mathrm{~N}_{2} \mathrm{O}$, was diluted to the desired concentration with $99.99995 \%$ grade $\mathrm{N}_{2}$.

A ferric chloride solution $\left(105 \mathrm{mmol} \mathrm{L}^{-1}\right)$ was prepared by dissolving $2.838 \mathrm{~g}$ of ferric chloride in $100 \mathrm{~mL}$ of water.

A chloroacetate buffer solution ( $\mathrm{pH} 2.4$ ) was prepared by dissolving $13.22 \mathrm{~g}$ of chloroacetic acid and $1.692 \mathrm{~g}$ of potassium hydroxide in $100 \mathrm{~mL}$ of water.

Artificial seawater (ASW) was prepared ${ }^{19}$ by dissolving $23.4 \mathrm{~g}$ of $\mathrm{NaCl}, 4.981 \mathrm{~g}$ of $\mathrm{MgCl}_{2}, 3.917 \mathrm{~g}$ of $\mathrm{Na}_{2} \mathrm{SO}_{4}, 1.102 \mathrm{~g}$ of $\mathrm{CaCl}_{2}, 0.664 \mathrm{~g}$ of $\mathrm{KCl}, 0.192 \mathrm{~g}$ of $\mathrm{NaHCO}_{3}, 0.096 \mathrm{~g}$ of $\mathrm{KBr}$, $0.026 \mathrm{~g}$ of $\mathrm{H}_{3} \mathrm{BO}_{3}, 0.024 \mathrm{~g}$ of $\mathrm{SrCl}_{2}$, and $0.003 \mathrm{~g}$ of $\mathrm{NaF}$ in $1 \mathrm{~kg}$ of water.

\section{Apparatus}

A Shimadzu GC-14B-type gas chromatograph with an ECD was used to detect $\mathrm{N}_{2} \mathrm{O}$. The $\mathrm{pH}$ of each solution was measured with a Horiba F-23 pH meter.

\section{Conditions of gas chromatography}

A stainless-steel column (length, $2 \mathrm{~m}$; i.d., $2.6 \mathrm{~mm}$ ) that was packed with Unibeads C (mesh 60/80, GL Sciences) was used at an oven temperature of $130^{\circ} \mathrm{C}$. The temperatures of the injector and detector (ECD) were 200 and $300^{\circ} \mathrm{C}$, respectively. The $99.99995 \%$-grade $\mathrm{N}_{2}$ carrier gas was used at a rate of $50 \mathrm{~mL}$ $\mathrm{min}^{-1}$. The water vapor in the sample was trapped with a sequential precolumn packed with $\mathrm{CaSO}_{4}$ before entering the Unibeads $C$ column. ${ }^{20}$

\section{Standard procedure}

Each water sample was transferred into a $70-\mathrm{mL}$ brown glass vial with glass beads that would mix the solution. The vial was capped with butyl rubber and an aluminum seal without any head-space to prevent air intrusion. Then, $1.0 \mathrm{~mL}$ of the chloroacetate buffer solution $(\mathrm{pH}=2.4)$ and $1.0 \mathrm{~mL}$ of the $105 \mathrm{mmol} \mathrm{L}^{-1}$ ferric chloride solution were injected (Fig. 1) to oxidize $\mathrm{NH}_{2} \mathrm{OH}$ to $\mathrm{N}_{2} \mathrm{O}$ at room temperature. A headspace technique was used to quantify the $\mathrm{N}_{2} \mathrm{O}$ generated. Then, $40 \mathrm{~mL}$ of $\mathrm{N}_{2}$ gas ( $99.99995 \%$ purity) was added to the vial using a magnum syringe for headspace analysis. After shaking the vial for several minutes, $0.2 \mathrm{~mL}$ of the headspace gas was injected into the gas chromatograph to measure the $\mathrm{N}_{2} \mathrm{O}$ in the headspace. The $\mathrm{N}_{2} \mathrm{O}$ concentration in the liquid phase was calculated using the Weiss and Price formula. ${ }^{21}$ For the blank, we performed each measurement with the addition of a buffer solution and ferric chloride solution against sample water free from $\mathrm{NH}_{2} \mathrm{OH}$. The $\mathrm{NH}_{2} \mathrm{OH}$ concentration was obtained by subtracting the $\mathrm{N}_{2} \mathrm{O}$ blank from the $\mathrm{N}_{2} \mathrm{O}$ signal generated by the buffer and a ferric chloride solutions. The detection limit of $\mathrm{N}_{2} \mathrm{O}$ by gas chromatography was $0.2 \mu \mathrm{gN} \mathrm{L} \mathrm{L}^{-1}$.

For the original $\mathrm{N}_{2} \mathrm{O}$ analysis in field studies, only formaldehyde ( $1 \%$ final concentration) was injected into the water samples to stop biological activity. This provided the original amount of dissolved $\mathrm{N}_{2} \mathrm{O}$ in the samples. For the $\mathrm{NH}_{2} \mathrm{OH}$ samples, $1.0 \mathrm{~mL}$ of a buffer solution and $1.0 \mathrm{~mL}$ of a ferric chloride solution were injected to oxidize $\mathrm{NH}_{2} \mathrm{OH}$ to $\mathrm{N}_{2} \mathrm{O}$. The resulting solutions were brought back to the laboratory for gas chromatographic measurements.

\section{Results and Discussion}

Optimum conditions for oxidizing hydroxylamine to nitrous oxide For the purpose of applying the proposed method to seawater as well as freshwater, the influence of salinity on the determination of $\mathrm{NH}_{2} \mathrm{OH}$ was also examined using artificial seawater.

\section{Effect of $p H$}

Samples were prepared with $\mathrm{H}^{+}$concentrations of 0.1 $0.01 \mathrm{~mol} \mathrm{~L}^{-1}$ and $\mathrm{pH}$ values of $2-8$. The ferric chloride solution had been added to both the freshwater (MQW) samples and the artificial seawater (ASW, 35\% ) samples, after which each of a dilute sodium hydroxide solution and a dilute sulfuric acid solution was added to the MQW samples and to the ASW 


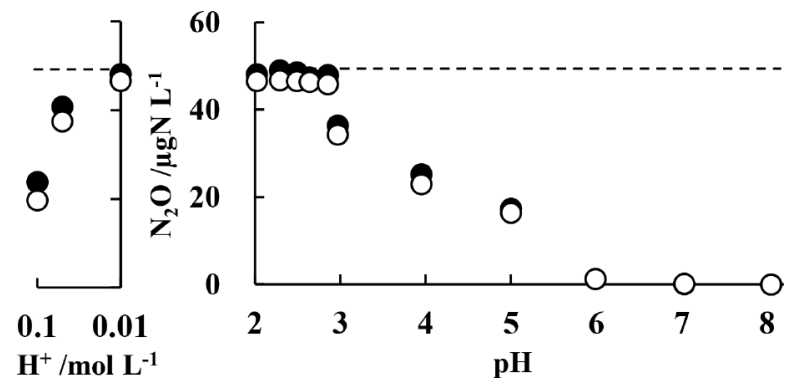

Fig. 2 Effect of the $\mathrm{pH}$ on the oxidation of $\mathrm{NH}_{2} \mathrm{OH}\left(50 \mu \mathrm{gN} \mathrm{L}^{-1}\right)$ to $\mathrm{N}_{2} \mathrm{O}$ in sample solutions prepared with freshwater (MQW, $\bullet$ ) and artificial seawater (35\% ASW, $\bigcirc)$. $1.0 \mathrm{~mL}$ of the $105 \mathrm{mmol} \mathrm{L}^{-1}$ ferric chloride solution was injected. These data shown are mean values $(n=2)$.

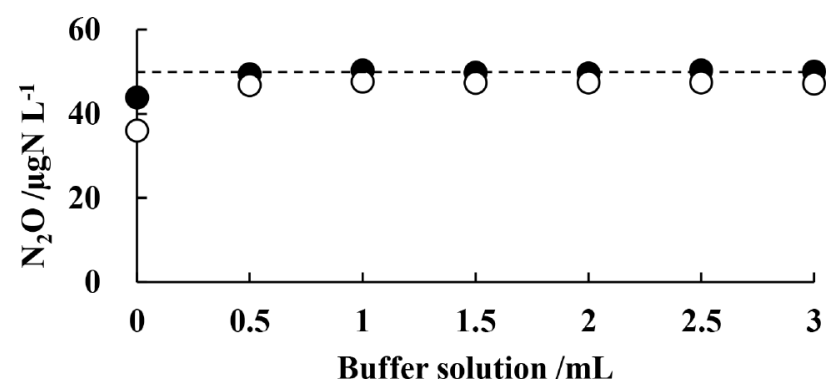

Fig. 3 Effect of the amount of buffer solution added on the oxidation of $\mathrm{NH}_{2} \mathrm{OH}\left(50 \mu \mathrm{gN} \mathrm{L}^{-1}\right)$ to $\mathrm{N}_{2} \mathrm{O}$ in sample solutions prepared with MQW (๑) and ASW (O). $1.0 \mathrm{~mL}$ of the $105 \mathrm{mmol} \mathrm{L}^{-1}$ ferric chloride solution was injected. These data shown are mean values $(n=2)$.

samples. The highest, constant value was obtained between a $\mathrm{pH}$ of 2.00 and 2.85 (Fig. 2), and we also attained a recovery of approximately $100 \%$. Thus, we were able to quantitatively recover $\mathrm{NH}_{2} \mathrm{OH}$ as $\mathrm{N}_{2} \mathrm{O}$. Our optimum $\mathrm{pH}$ range $(2.00-2.85)$ was different from that $(2.8-3.5)$ determined by Butler and Gordon. ${ }^{18}$ However, we obtained similar results, where our recovery of $\mathrm{NH}_{2} \mathrm{OH}$ as $\mathrm{N}_{2} \mathrm{O}$ was $71 \%$ at a $\mathrm{pH}$ of 3.0 , while Butler and Gordon achieved their maximum conversion of $80 \%$ at a $\mathrm{pH}$ of $2.9-3.0$.

\section{Effect of buffer solution addition}

Butler and Gordon ${ }^{18}$ reported low recoveries $(40-83 \%)$ of $\mathrm{NH}_{2} \mathrm{OH}$ as $\mathrm{N}_{2} \mathrm{O}$ when acidifying their samples to a $\mathrm{pH}$ of 2.9 - 3.0 using an acetate solution as their buffer. Our study employed the optimum $\mathrm{pH}$ range of $2.00-2.85$ (Fig. 2); therefore, we chose not an acetate solution, but a chloroacetate solution ( $\mathrm{pH} 2.4)$ as our buffering agent to adjust to a $\mathrm{pH}$ of $2.35-2.50$. To confirm its suitability, we examined the effects of the amount of chloroacetate solution added to the sample water on the conversion of $\mathrm{NH}_{2} \mathrm{OH}$ to $\mathrm{N}_{2} \mathrm{O}$ (Fig. 3). We found that adding $0.5-3.0 \mathrm{~mL}$ of the chloroacetate solution to $70 \mathrm{~mL}$ of the sample solution adjusted the $\mathrm{pH}$ of $2.35-2.50$ and achieved quantitative recoveries of $\mathrm{NH}_{2} \mathrm{OH}$ from $\mathrm{N}_{2} \mathrm{O}$. From these results, we chose to add $1.0 \mathrm{~mL}$ of a chloroacetate solution to the samples in subsequent experiments.

\section{Effect of the $\mathrm{Fe}^{3+}$ concentration}

$\mathrm{NH}_{2} \mathrm{OH}$ standard solutions with concentrations of 50 and $20 \mu \mathrm{gN} \mathrm{L}^{-1}$ (3.57 and $\left.1.43 \mu \mathrm{mol} \mathrm{L}^{-1}\right)$ were tested against MQW and ASW (35\%) samples, respectively, to determine the effect

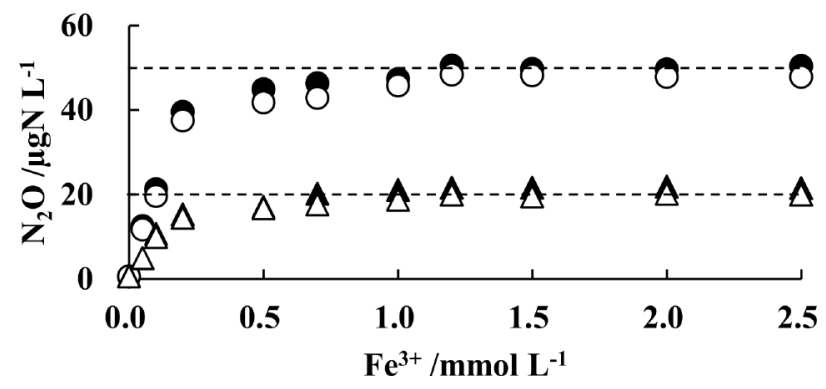

Fig. 4 Effect of the $\mathrm{Fe}^{3+}$ concentration on the oxidation of $\mathrm{NH}_{2} \mathrm{OH}$ (20 and $50 \mu \mathrm{gN} \mathrm{L}^{-1}$ ) to $\mathrm{N}_{2} \mathrm{O}$ in sample solutions prepared with MQW and ASW. $1.0 \mathrm{~mL}$ of the chloroacetate buffer solution $(\mathrm{pH}=2.4)$ was injected. $\boldsymbol{\Delta}, \mathrm{NH}_{2} \mathrm{OH}\left(20 \mu \mathrm{gN} \mathrm{L}^{-1}\right)$ in $\mathrm{MQW} ; \triangle, \mathrm{NH}_{2} \mathrm{OH}\left(20 \mu \mathrm{gN} \mathrm{L}^{-1}\right)$ in ASW; $\bullet, \mathrm{NH}_{2} \mathrm{OH}\left(50 \mu \mathrm{gN} \mathrm{L}^{-1}\right)$ in MQW; $\bigcirc, \mathrm{NH}_{2} \mathrm{OH}\left(50 \mu \mathrm{gN} \mathrm{L}^{-1}\right)$ in ASW. These data shown are mean values $(n=2)$.

of the $\mathrm{Fe}^{3+}$ concentration on the oxidation of $\mathrm{NH}_{2} \mathrm{OH}$ to $\mathrm{N}_{2} \mathrm{O}$. These experiments were each conducted at a $\mathrm{pH}$ of $2.35-2.50$, for $2 \mathrm{~h}$, at $25^{\circ} \mathrm{C}$. When the concentration of $\mathrm{Fe}^{3+}$ was in the range of $1.2-2.5 \mathrm{mmol} \mathrm{L}^{-1}$, the recovery of $\mathrm{NH}_{2} \mathrm{OH}$ from both the 50 and $20 \mu \mathrm{gN} \mathrm{L}^{-1}$ solutions was approximately $100 \%$ (Fig. 4). Therefore, the ferric chloride concentration adopted for our proposed method was $1.5 \mathrm{mmol} \mathrm{L}^{-1}$, which corresponds to the final concentration when $1.0 \mathrm{~mL}$ of $105 \mathrm{mmol} \mathrm{L}^{-1}$ ferric chloride solution was added to $70 \mathrm{~mL}$ of the water sample.

\section{Effect of the standing time}

After adding a ferric chloride solution, the highest recovery was obtained after $1 \mathrm{~h}$, where it remained constant, indicating that the oxidation reaction of $\mathrm{NH}_{2} \mathrm{OH}$ to $\mathrm{N}_{2} \mathrm{O}$ by the $\mathrm{Fe}$ (III) solution was completed in about $1 \mathrm{~h}$. The resultant $\mathrm{N}_{2} \mathrm{O}$ was stable for at least 10 days (data not shown). For this study, we adopted $2 \mathrm{~h}$ as the standing time.

\section{Effects of diverse ions}

The seawater contains $\mathrm{Na}^{+}, \mathrm{Mg}^{2+}, \mathrm{Ca}^{2+}, \mathrm{K}^{+}, \mathrm{Cl}^{-}, \mathrm{SO}_{4}{ }^{2-}$, and $\mathrm{HCO}_{3}{ }^{-}$at extremely high levels: such ions universally exist in fresh river and lake waters only at low levels. As can be seen from Figs. $2-4, \mathrm{NH}_{2} \mathrm{OH}$ was able to be determined even in seawater samples.

Nitrogen species other than $\mathrm{NH}_{2} \mathrm{OH}$, such as $\mathrm{NH}_{4}^{+}, \mathrm{NO}_{2}^{-}$, $\mathrm{NO}_{3}{ }^{-}$, urea, and amino acids, are present in environmental water. We investigated the effects of these substances on the determination of $\mathrm{NH}_{2} \mathrm{OH}$ using our improved $\mathrm{Fe}(\mathrm{III})$ method. No interference was observed by $\mathrm{NH}_{4}{ }^{+}, \mathrm{NO}_{2}^{-}$, or $\mathrm{NO}_{3}{ }^{-}$over the range of 0 to $1000 \mu \mathrm{gN} \mathrm{L}^{-1}$, and neither urea nor several amino acids interfered with concentrations over the range of 0 to $100 \mu \mathrm{gN} \mathrm{L} \mathrm{L}^{-1}$ (Table 1).

However, $500 \mu \mathrm{gN} \mathrm{L}^{-1}$ or greater of nitrite has been observed to interfere with $\mathrm{NH}_{2} \mathrm{OH}$ detection by the hypochlorite method. ${ }^{16}$ However, no interference due to nitrite at concentrations up to $1000 \mu \mathrm{gN} \mathrm{L}^{-1}$ was observed in our proposed method.

\section{Effect of organic matter (Chl-a)}

When using the hypochlorite method ${ }^{15,16}$ to measure samples that contained organic substances (especially phytoplankton), it was suggested that some of the measurements could be underestimated (unpublished data). Therefore, we investigated the $\mathrm{NH}_{2} \mathrm{OH}$ recovery of the hypochlorite method and our improved $\mathrm{Fe}(\mathrm{III})$ method using the same water samples that contained phytoplankton (Fig. 5). The water sample that contained phytoplankton was taken in epilimnion of brackish 
Table 1 Effects of ammonium, nitrite, nitrate, amino acids, and urea on the recovery of $\mathrm{NH}_{2} \mathrm{OH}\left(50 \mu \mathrm{gN} \mathrm{L}^{-1}\right)$ as $\mathrm{N}_{2} \mathrm{O}$ using the improved $\mathrm{Fe}(\mathrm{III})$ method

\begin{tabular}{|c|c|c|c|}
\hline Sample & Found $/ \mu g \mathrm{~g} \mathrm{~L}^{-1}$ & Recovery, \% & $\operatorname{RSD}(n=3), \%$ \\
\hline $\mathrm{NH}_{2} \mathrm{OH}(50)$ only & 49.5 & 99.0 & 0.7 \\
\hline Ammonium $(1000)+\mathrm{NH}_{2} \mathrm{OH}(50)$ & 49.8 & 99.7 & 0.1 \\
\hline Nitnite $(1000)+\mathrm{NH}_{2} \mathrm{OH}(50)$ & 49.5 & 99.0 & 0.8 \\
\hline Nitrate $(1000)+\mathrm{NH}_{2} \mathrm{OH}(50)$ & 49.7 & 99.4 & 0.7 \\
\hline Glycine $(100)+\mathrm{NH}_{2} \mathrm{OH}(50)$ & 49.2 & 98.4 & 0.2 \\
\hline L-Glutamic acid $(100)+\mathrm{NH}_{2} \mathrm{OH}(50)$ & 49.5 & 99.1 & 0.3 \\
\hline L-Phenylalanine $(100)+\mathrm{NH}_{2} \mathrm{OH}(50)$ & 49.3 & 98.5 & 0.5 \\
\hline $\mathrm{L}-\alpha$-Alanine $(100)+\mathrm{NH}_{2} \mathrm{OH}(50)$ & 49.3 & 98.7 & 0.2 \\
\hline L-Lysine monohydrochloride $(100)+\mathrm{NH}_{2} \mathrm{OH}(50)$ & 49.5 & 99.1 & 0.5 \\
\hline Urea (100) + $\mathrm{NH}_{2} \mathrm{OH}(50)$ & 49.5 & 99.0 & 0.4 \\
\hline
\end{tabular}

a. The values in parenthese are concentration of each substance in $\mu \mathrm{gN} \mathrm{L}^{-1}$.

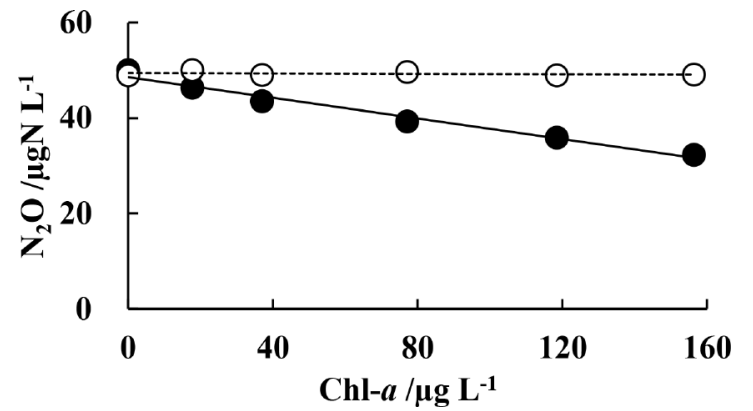

Fig. 5 Effect of an organic substance (Chl- $a$ ) on the oxidation of $\mathrm{NH}_{2} \mathrm{OH}\left(50 \mu \mathrm{gN} \mathrm{L}^{-1}\right)$ to $\mathrm{N}_{2} \mathrm{O}$ by the hypochlorite method $(\bullet)$ and the improved Fe(III) method $(\bigcirc)$. $1.0 \mathrm{~mL}$ of the chloroacetate buffer solution $(\mathrm{pH}=2.4)$ and $1.0 \mathrm{~mL}$ of the $105 \mathrm{mmol} \mathrm{L}^{-1}$ ferric chloride solution were injected.

Lake Shinji. The suspended substance (mainly phytoplankton) in water samples was collected on a membrane filter $(0.5 \mu \mathrm{m})$, and the Chl- $a$ concentration in each sample was adjusted accordingly using the suspension on the filter and its filtered water. Since the filtered water was used to dilute each sample, the salinity in all samples was constant. The recovery of the hypochlorite method decreased with increasing the Chl- $a$ concentration, while that of our proposed method was high and remained constantly regardless of Chl- $a$ concentration. The decrease in the recovery of the hypochlorite method was due to a lack of hypochlorite, resulting from phytoplankton decomposition. Thus, in the case of samples containing high amounts of various kinds of organic substances, that come from phytoplankton, it was necessary to add an excess amount of hypochlorite compared with the conventional method. Our improved $\mathrm{Fe}$ (III) method did not exhibit a decrease in the recovery because the weak oxidation of $\mathrm{Fe}(\mathrm{III})$ did not contribute to the decomposition of phytoplankton. Based on these results, a suitable method must be selected for testing in various environments.

\section{Calibration curve, recovery and reproducibility}

When a calibration curve was drawn in the range of 0 to $100 \mu \mathrm{gN} \mathrm{L}^{-1}$, a good result with a high linearity $(y=0.001 x+$ 0.0975 and $R^{2}=0.9991$ ) was obtained.

To confirm the recovery of $\mathrm{NH}_{2} \mathrm{OH}$ as $\mathrm{N}_{2} \mathrm{O}$ by the proposed method, we performed experiments in which 20 and $50 \mu \mathrm{gN} \mathrm{L}^{-1}$ solutions of $\mathrm{NH}_{2} \mathrm{OH}$ were added to freshwater and brackish-
Table 2 Recovery of $\mathrm{NH}_{2} \mathrm{OH}$ ( 20 and $50 \mu \mathrm{gN} \mathrm{L}^{-1}$ ) added to the natural freshwater and brackish-water samples using the improved $\mathrm{Fe}(\mathrm{III})$ method

\begin{tabular}{|c|c|c|c|c|c|}
\hline \multirow{2}{*}{ Sample } & \multirow{2}{*}{$\begin{array}{l}\text { Added/ } \\
\mu \mathrm{gN} \mathrm{L}{ }^{-1}\end{array}$} & \multirow{2}{*}{$\begin{array}{l}\text { Found/ } \\
\mu \mathrm{gN} \mathrm{L}^{-1}\end{array}$} & \multicolumn{2}{|c|}{ Recovery } & \multirow{2}{*}{$\begin{array}{c}\text { RSD } \\
(n=5) \\
\%\end{array}$} \\
\hline & & & $\mu \mathrm{gN} \mathrm{L}^{-1}$ & $\%$ & \\
\hline \multirow{3}{*}{$\begin{array}{l}\text { Hii river } \\
\text { (Freshwater) }\end{array}$} & 0 & 0.6 & - & - & - \\
\hline & 20 & 21.3 & 20.6 & 103 & 2.1 \\
\hline & 50 & 51.5 & 50.9 & 102 & 2.1 \\
\hline \multirow{3}{*}{$\begin{array}{l}\text { Lake Shinji } \\
\text { (Salinity, 8.0\%o) }\end{array}$} & 0 & 0.4 & - & - & - \\
\hline & 20 & 20.2 & 19.8 & 99 & 1.3 \\
\hline & 50 & 50.9 & 50.6 & 101 & 1.2 \\
\hline \multirow{3}{*}{$\begin{array}{l}\text { Lake Nakaumi } \\
\text { (Salinity, } 24.8 \% \text { ) }\end{array}$} & 0 & 0.6 & - & - & - \\
\hline & 20 & 20.5 & 19.9 & 99 & 2.1 \\
\hline & 50 & 51.4 & 50.9 & 102 & 1.1 \\
\hline
\end{tabular}

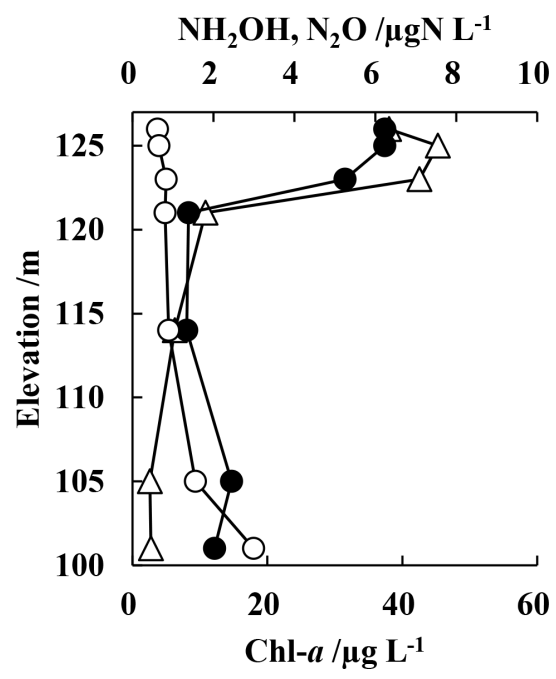

Fig. 6 Vertical distributions of $\mathrm{NH}_{2} \mathrm{OH}, \mathrm{N}_{2} \mathrm{O}$, and Chl- $a$ present in samples from the Sanbe-dam reservoir (collected September 25, 2019). ๑, $\mathrm{NH}_{2} \mathrm{OH} ; \bigcirc, \mathrm{N}_{2} \mathrm{O} ; \triangle$, Chl- $a$.

water samples, respectively. $\mathrm{NH}_{2} \mathrm{OH}$ was quantitatively recovered from the water samples in a range of 99 to $103 \%$ with a relative standard deviation (RSD) of 1.1 to $2.1 \%$ (Table 2). 


\section{Application to environmental water samples}

The proposed method was applied to a water sample from the Sanbe-dam reservoir, collected on September 25, 2019. Sample water was taken with a Kitahara-type sampler and transferred to a brown glass vial $(70 \mathrm{~mL})$. Then, $1.0 \mathrm{~mL}$ of a buffer solution (pH 2.4) and $1.0 \mathrm{~mL}$ of a ferric chloride solution $\left(105 \mathrm{mmol} \mathrm{L}^{-1}\right)$ were added to determine the amount of $\mathrm{NH}_{2} \mathrm{OH}$ as $\mathrm{N}_{2} \mathrm{O}$. For the original $\mathrm{N}_{2} \mathrm{O}$ analysis, formaldehyde ( $1 \%$ final concentration) was added to stop biological activity. These procedures were performed in situ, and then the samples were transported to the laboratory. The headspace technique using gas chromatography was then employed to measure the $\mathrm{N}_{2} \mathrm{O}$ concentration. The vertical distributions of $\mathrm{NH}_{2} \mathrm{OH}, \mathrm{N}_{2} \mathrm{O}$, and Chl- $a$ are shown in Fig. 6. An interesting phenomenon was observed, where $\mathrm{NH}_{2} \mathrm{OH}$ and Chl- $a$ exhibited a similar behavior. It seems likely that this $\mathrm{NH}_{2} \mathrm{OH}$ might be derived from phytoplankton.

\section{Conclusions}

We developed a method for determining nanomolar $\mathrm{NH}_{2} \mathrm{OH}$ concentrations in environmental water based on $\mathrm{Fe}^{3+}$ oxidation. To detect the $\mathrm{NH}_{2} \mathrm{OH}$ concentration, a chloroacetate solution (buffer) and a ferric chloride solution (oxidant) were added to the sample solutions to oxidize $\mathrm{NH}_{2} \mathrm{OH}$ to $\mathrm{N}_{2} \mathrm{O}$, which was then quantified by headspace analysis using a gas chromatograph equipped with an ECD. Our method exhibited a high $\mathrm{NH}_{2} \mathrm{OH}$ recovery and good reproducibility when testing various samples from freshwater, brackish water, and seawater sources in Japan. In addition, it was also applicable to samples rich in organic substances, derived from phytoplankton.

\section{Acknowledgements}

Parts of this study were performed with support from the Ministry of Education, Culture, Sports, Science and Technology Grant-in-Aid for Scientific Research (No. 19K22910). We would like to thank Editage (www.editage.jp) for English language editing.

\section{References}

1. Y. Seike, K. Kondo, H. Hashitani, M. Okumura, K. Fujinaga, and Y. Date, Jpn. J. Limnol., 1990, 51, 137.

2. Y. Senga, Y. Seike, K. Mochida, K. Fujinaga, and M. Okumura, Limnology, 2001, 2, 129.

3. Y. Senga, K. Mochida, N. Okamoto, R. Fukumori, and Y. Seike, Limnology, 2002, 3, 21.

4. T. Hofman and H. Lees, Biochem. J., 1952, 54, 579.

5. M. Tanaka, Nature, 1953, 171, 1160.

6. M. Oshiki, M. Ali, K. Shinyako-Hata, H. Satoh, and S. Okabe, Environ. Microbiol., 2016, 18, 3133.

7. K. Kobayashi, A. Makabe, M. Yano, M. Oshiki, T. Kindaichi, K. L. Casciotti, and S. Okabe, ISME J., 2019, 13, 2426.

8. B. Kartal and T. Keltjens, Trends Biochem. Sci., 2016, 41, 998.

9. M. Fiadeiro, L. Solorzano, and J. D. H. Strickland, Limnol. Oceanogr., 1967, 12, 555.

10. J. H. Anderson, Analyst, 1964, 89, 357.

11. L. R. Pittwell, Microchim. Acta., 1975, 64, 425.

12. R. Fukumori, Y. Senga, M. Okumura, K. Fujinaga, and Y. Seike, Bunseki Kagaku, 2003, 52, 747.

13. A. Afkhami, T. Madrakian, and A. Maleki, Anal. Sci., 2006, 22, 329.

14. W. D. Korte, J. Chromatogr., 1992, 603, 145.

15. Y. Seike, R. Fukumori, Y. Senga, H. Oka, K. Fujinaga, and M. Okumura, Anal. Sci., 2004, 20, 139.

16. T. Kato, S. Sugahara, M. Murakami, Y. Senga, M. Egawa, H. Kamiya, K. Omata, and Y. Seike, Anal. Sci., 2017, 33, 691.

17. M. T. von Breymann, M. A. de Angells, and L. I. Gordon, Anal. Chem., 1982, 54, 1209.

18. J. H. Butler and L. I. Gordon, Mar. Chem., 1986, 19, 229.

19. J. P. Riley and G. Skirrows, "Chemical Oceanography", 1965, Academic Press, New York, 648.

20. Y. Senga, K. Mochida, R. Fukumori, N. Okamoto, and Y. Seike, Estuarine Coastal Shelf Science, 2006, 67, 231.

21. R. F. Weiss and B. A. Price, Mar. Chem., 1980, 8, 347. 